\title{
Pengaruh Image Engagement pada Aplikasi Parasit Malaria
}

\author{
Muhammad Irsan Sabir ${ }^{* 1}$, Muhammad Niswar ${ }^{2}$, Indrabayu ${ }^{2}$ \\ ${ }^{1}$ Departemen Teknik Elektro, Fakultas Teknik, Universitas Hasanuddin \\ Jl. Poros Malino Km. 6, Bontomarannu, Kabupaten Gowa, Sulawesi Selatan, 92171 \\ ${ }^{2}$ Departemen Teknik Informatika, Fakultas Teknik, Universitas Hasanuddin \\ J1. Poros Malino Km. 6, Bontomarannu, Kabupaten Gowa, Sulawesi Selatan, 92171 \\ *Email: muhammadirsansabir@gmail.com
}

DOI: 10.25042/jpe.052018.06

\begin{abstract}
Abstrak
Parasit nyamuk merupakan sekelompok mikroorganisme bersel tunggal dalam tipe plasmodium yang dapat menyebabkan malaria dengan menyerang sel darah manusia. Dalam penelitian ini, sebuah aplikasi pendeteksi parasit jenis Plasmodium Falciparum pada stadium thropozoit, skizon dan gametosit dirancang dengan menggunakan Android Studio 2.2.2 dan library OpenCV 2.4.9. Proses deteksi citra diawali dengan preprocessing citra selanjutnya tahap fitur ekstraksi dan klasifikasi menggunakan metode Haar Cascade Classifier, kemudian tahap terakhir 3 jenis boost dibandingkan, yaitu Gentle Adaboost, Discrete Adaboost, dan Real Adaboost. Image Enhancement merupakan salah satu proses awal dalam preprocessing yang bertujuan untuk memperjelas ciri atau fitur tertentu dari citra agar lebih mudah dianalisa secara teliti pada proses seleksi fitur. Hasil penelitian ini membuktikan bahwa image enhancement dapat digunakan untuk meningkatkan kualitas citra agar informasi yang ada pada citra dapat terlihat lebih jelas.
\end{abstract}

\begin{abstract}
Effect of Image Engagement on Malaria Parasite Applications. The mosquito's parasite is a group of single-celled microorganisms in the plasmodium type that can cause malaria by attacking human blood cells. In this study, a parasitic detection application of Plasmodium Falciparum type at thropozoite, scizont and gametocyte stage was designed using Android Studio 2.2.2 and OpenCV 2.4.9 library. Image detection process begins with preprocessing, then feature extraction and classification phase using Haar Cascade Classifier, then the last stage 3 types of boost compared, namely Gentle Adaboost, Discrete Adaboost, and Real Adaboost. Image Enhancement is one of the preliminary processes in preprocessing that aims to clarify certain features or features of the image to be more easily analyzed carefully in the feature selection process. The results of this study prove that image enhancement can be used to improve image quality so that the information available on the image can be seen more clearly.
\end{abstract}

Kata Kunci: Android studio, image enhancement, malaria parasites, preprocessing

\section{Pendahuluan}

Malaria merupakan jenis penyakit yang diakibatkan oleh parasit dari genus plasmodium yang disebabkan oleh gigitan nyamuk anopheles betina dengan menyerang eritrosit atau sel darah merah manusia. Beberapa jenis plasmodium yang dapat menyerang tubuh manusia antara lain : plasmodium vivax yang menyebabkan malaria tertiana, plasmodium malaria yang menyebabkan malaria kuartana, plasmodium ovale menyebabkan malaria ovale, sedangkan plasmodium falciparum menyebabkan malaria tropika, jenis plasmodium ini dapat menimbulkan berbagai komplikasi di dalam organ-organ tubuh.
Menurut data statistik yang diperoleh Riset Kesehatan Dasar (Riskesda) pada tahun 2010, dinyatakan bahwa spesies parasit malaria terbanyak yang ditemukan di wilayah Indonesia yaitu jenis plasmodium falciparum yang dapat mengakibatkan malaria falciparum, dengan angka prevalensi sebesar 86,4 \% [1].

Berbagai pemeriksaan standar dilakukan oleh para ahli untuk mengenali parasit malaria yang terdapat pada sel darah manusia dengan menggunakan alat mikroskopis. Proses dan waktu yang banyak dibutuhkan dalam sebuah laboratorium untuk mendapatkan hasil dari citra darah mikroskopis. Sebuah sistem diperlukan agar 
dapat memberikan kemudahan dalam pendeteksian parasit pada citra darah yang dapat digunakan kapan pun dan di manapun untuk menghemat tenaga dan waktu.

Penelitian sebelumnya telah dilakukan oleh Rakshit dan Bhowmik [2], melakukan penelitian untuk mendeteksi citra darah yang dengan beberapa bentuk plasmodium (Ring trophozoite, merozoite, schizont), dengan menggunakan deteksi tepi sobel dan Harris Corner Point.

Selanjutnya Permata [3], dengan tujuan penelitian membangun sistem klasifikasi fase parasit malaria plasmodium vivax menggunakan metode Support Vector Machine (SVM) dengan hasil akurasi vivax thropozoit 91,67\%, vivax schizont $87,78 \%$ dan vivax gametocyte $84,44 \%$.

Kemudian, Khatkar dan Kumar [4], melakukan penelitian untuk memperbaiki kualitas citra biomedis dengan menggunakan algoritma SIFT serta wavelet D'Mayer dan Coieflet.

Penelitian ini bertujuan untuk mendeteksi penyakit malaria jenis plasmodium falciparum pada stadium trophozoit, schizont, dan gametosit melalui citra darah dengan melakukan Image Engagement pada tahap pre processing dan menggunakan metode haar cascade classifier pada tahap klasifikasi parasit.

\section{Metodologi}

Penelitian ini dilakukan di Laboratorium Jaringan Komputer, Universitas Hasanuddin Makassar. Data yang digunakan pada penelitian ini adalah data pimer yaitu data berupa citra yang diperoleh dari laboratorium dengan format JPG dan citra Plasmodium Falciparum dari phil.CDC.gov. Data latih yang digunakan dibagi menjadi 2 jenis, yaitu data positif berjumlah 100 citra darah yang terinfeksi parasit malaria dan data negatif berjumlah 200 citra darah normal. Sedangkan untuk data uji menggunakan 70 citra darah yang terindikasi parasit dengan 3 stadium yaitu stadium tropozoit 20 citra, stadium skizon 20 citra, dan stadium gametosit 30 citra. Data yang digunakan pada penelitian ini adalah data primer yaitu data berupa citra yang diperoleh dari laboratorium dengan format JPG dan citra Plasmodium Falciparum dari phil.CDC.gov.
Kemudian data tersebut akan diolah dengan menggunakan perangkat lunak Android Studio dan OpenCV. Data yang akan digunakan terbagi atas 2 bagian, data latih dan data uji. Data sekunder berupa literatur, referensi jurnal ataupun laporan penelitian yang terkait serta sumber lain yang dianggap menunjang penelitian [5]. Perancangan sistem yang diusulkan ditujukkan pada Gambar 1.

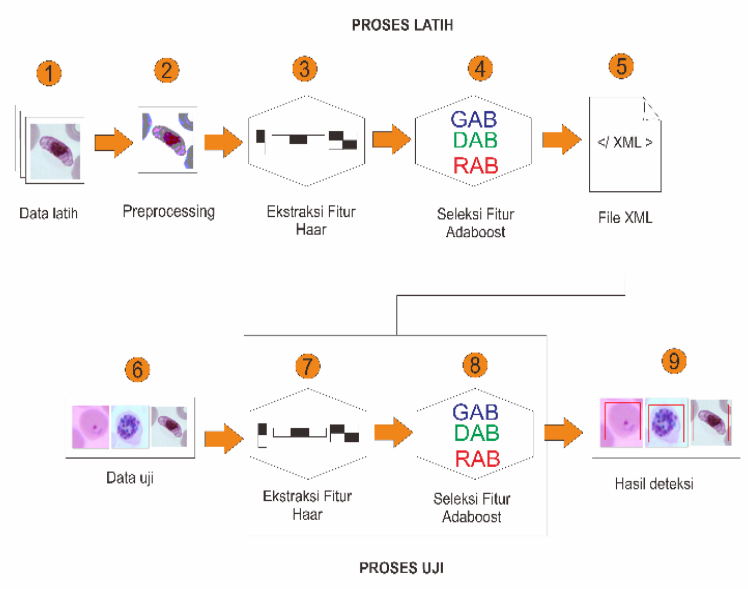

Gambar 1. Desain sistem

Secara umum rancangan penelitian ini dapat dijelaskan sebagai berikut, tahap awal yang dilakukan adalah mengumpulkan data citra darah manusia yang terinfeksi parasit malaria dan darah yang normal, citra darah tersebut dibagi ke dalam citra darah latih dan citra darah uji. Citra darah latih di bagi menjadi 2 jenis yaitu citra darah positif (terinfeksi parasit) dan citra darah negatif (citra darah tanpa parasit).

Tahap prepocessing dilakukan untuk mengubah kualitas citra dengan memperjelas ciri atau fitur tertentu dari citra agar lebih mudah dianalisa secara teliti pada proses seleksi fitur. Pada tahap ini, citra diproses seperti melakukan Image Brightness atau pengubahan kecerahan gambar dilakukan untuk memperbaiki kualitas dari citra atau gambar. Kecerahan gambar dapat diperbaiki dengan menambahkan (atau mengurangkan) sebuah konstanta kepada (atau dari) setiap pixel di dalam citra. Akibat dari operasi ini, histogram citra mengalami pergeseran. 


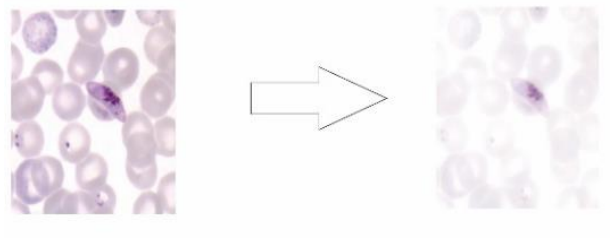

Peningkatan kecerahan

Gambar 2. Peningkatan kecerahan citra

Pada tahap selanjutnya, fitur-fitur dari citra diekstraksi untuk menghasilkan sebuah file XML. Tahap selanjutnya adalah menghubungkan data uji dan data latih untuk menghasilkan deteksi citra parasit pada darah yang normal dan terinfeksi parasit. Metode analisis data yang di gunakan yaitu proses perangkat lunak yang sekuensial [6].

Penelitian ini terdiri atas 2 tahapan, yaitu tahap pelatihan dan tahap pengujian seperti yang di perlihatkan pada gambar 1, ekstraksi fitur dan pengklasifikasian menggunakan haar cascade classifier dan perbandingan 3 jenis adaboost pada proses seleksi fitur. Hasil seleksi fitur tersebut disimpan dalam bentuk file XML. Sampel positif berisi citra objek parasit yang ingin di deteksi dengan ciri seperti pada Tabel 1 di bawah.

Tabel 1. Ciri dari tiap stadium parasit malaria Plasmodium Falciparum

\begin{tabular}{cl}
\hline Stadium & \multicolumn{1}{c}{ Ciri } \\
\hline \multirow{3}{*}{ Trophozoit } & Berbentuk seperti cincin \\
& Terdapat titik-titik maurer \\
& Eritrosit yang terinfeksi tidak \\
& membesar \\
& Terdapat pigmen menggumpal, \\
Skizon & merozoit dan titik maurer \\
& Eritrosit yang terinfeksi tidak \\
& membesar \\
& Berbentuk seperti sosis / pisang \\
Gametosit & Eritrosit yang terinfeksi \\
& membesar \\
\hline
\end{tabular}

Pada tahapan analisis sistem dilakukan dengan melakukan studi awal mengenai stage dan morfologi dari jenis Plasmodium Falciparum. Data diambil dengan cara mengamati, wawancara dan mengumpulkan literatur praktikum berupa citra darah manusia, waktu yang digunakan dalam pendeteksian citra serta bahan dan alat yang dibutuhkan dalam proses pengenalan Plasmodium Falciparum. Untuk melengkapi tahapan ini dilakukan pula studi literatur mengenai parasit malaria, perangkat lunak serta metode yang digunakan.

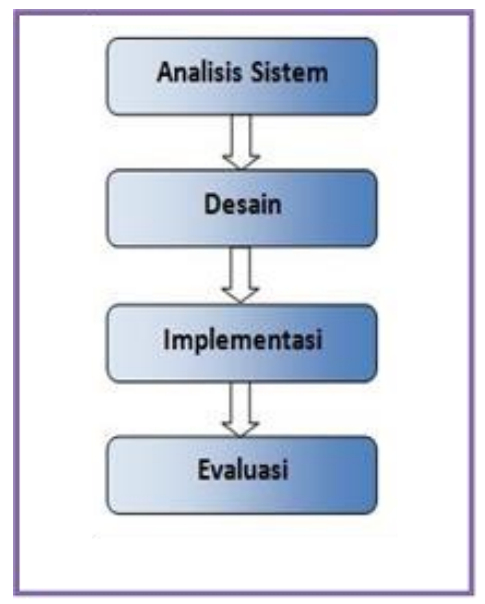

Gambar 3. Tahapan analisis sistem

Pada tahap pengujian, recall rate digunakan untuk mendapatkan hasil dari perbandingan ketiga boost pada masing-masing stadium parasit plasmodium falciparum. Recall rate adalah rasio jumlah area parasit yang benar terdeteksi sebagai parasit (true positive) terhadap jumlah area parasit yang benar terdeteksi sebagai parasit (true positive) dan jumlah area parasit yang salah terdeteksi sebagai bukan parasit (false negative). Berikut persamaan yang digunakan :

$$
\text { Recall Rate }=\frac{R T}{T P+F N}
$$

Dimana:
TP

(true positive)

FN

(false negative)
= jumlah area parasit yang benar terdeteksi sebagai parasit $=$ jumlah area parasit yang terdeteksi sebagai bukan parasit

\section{Hasil}

Sistem dirancang dengan menggunakan perangkat lunak Android Studio 2.2 dengan library OpenCV 2.4.9. Hasil rancangan aplikasi dijalankan pada sebuah smartphone android. Gambar 4 menunjukkan tampilan aplikasi dari hasil deteksi parasit pada stadium tropozoit, skizon, dan gametosit. 


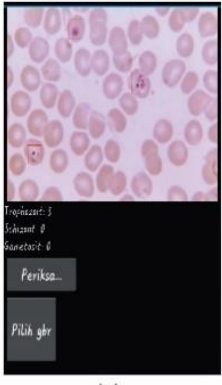

(a)

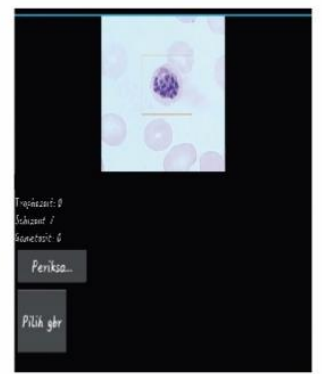

(b)

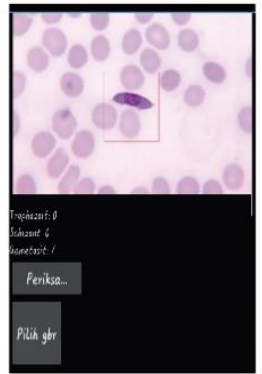

(c)
Gambar 4. Tampilan program yang dirancang, (a) Parasit stadium trophozoit, (b) Parasit stadium skizon, (c) Parasit stadium gametosit

Hasil dari proses pengenalan dan klasifikasi stadium parasit malaria jenis plasmodium falciparum dilakukan dengan validasi dalam 3 tahap yaitu dengan menggunakan Gentle Adaboost, Discrete Adaboost, dan Real Adaboost. Dalam perancangan sistem, parameter yang digunakan adalah akurasi yang dihasilkan dari recall rate untuk mengetahui boost yang memiliki akurasi paling baik.

Hasil dari proses pengujian recall rate untuk stadium trophozit pada Gentle Adaboost (GAB) dihasilkan recall rate sebesar 70\%, untuk Discrete Adaboost (DAB) dihasilkan nilai recall rate sebesar 75\% dan Real Adaboost (RAB) dihasilkan nilai recall rate sebesar $70 \%$. Selanjutnya, hasil dari proses pengujian recall rate untuk stadium schizont pada Gentle Adaboost (GAB) dihasilkan recall rate sebesar 55\%, untuk Discrete Adaboost (DAB) dihasilkan nilai recall rate sebesar $85 \%$ dan Real Adaboost (RAB) dihasilkan nilai recall rate sebesar $85 \%$. Kemudian pada stadium gametosit, hasil pengujian recall rate pada Gentle Adaboost (GAB) dihasilkan recall rate sebesar 87\%, untuk Discrete Adaboost (DAB) dihasilkan nilai recall rate sebesar 70\% dan Real Adaboost (RAB) dihasilkan nilai recall rate sebesar $60 \%$.

Tabel 2. Hasil pengujian

\begin{tabular}{cccc}
\hline Recall Rate & $\begin{array}{c}\text { Gentle } \\
\text { Adaboost }\end{array}$ & $\begin{array}{c}\text { Discrete } \\
\text { Adaboost }\end{array}$ & $\begin{array}{c}\text { Real } \\
\text { Adaboost }\end{array}$ \\
\hline Trophozoit & $70 \%$ & $75 \%$ & $75 \%$ \\
\hline Skizon & $55 \%$ & $85 \%$ & $85 \%$ \\
\hline Gametosit & $87 \%$ & $70 \%$ & $60 \%$ \\
\hline
\end{tabular}

\section{Kesimpulan}

Berdasarkan hasil pengujian, pengaruh image engagement pada aplikasi parasit malaria dapat meningkatkan akurasi pendeteksian parasit pada tiap stadium sehingga membantu para peneliti dalam mengenali parasit malaria jenis Plasmodium Falciparum pada tiga stadium yaitu trophozoit, schizont, dan gametosit. Nilai recall rate paling tinggi dihasilkan Discrete Adaboost dan Real Adaboost dengan recall rate masingmasing $75 \%$ pada stadium thropozoit dan $85 \%$ pada stadium schizont. Sedangkan pada stadium gametosit, boost yang menghasilkan akurasi paling baik adalah Gentle Adaboost dengan recall rate sebesar $87 \%$. Aplikasi ini memberikan peningkatan nilai dan perbedaan waktu pelacakan yang signifikan dibandingkan tanpa menggunakan aplikasi dalam proses identifikasi parasit malaria. Sistem ini dapat bermanfaat untuk digunakan berkelanjutan.

\section{Referensi}

[1] Departemen Kesehatan, 2015. "Rencana Strategis Kementrian Kesehatan 2015-2019”, Keputusan Menteri Kesehatan Republik Indonesia Nomor HK.02.02/Menkes/52/2015.

[2] Rakshit P. \& Bhowmik K., 2013. "Detection of presence of Parasites in Human RBC In Case of Diagnosing Malaria Using Image Processing", Proceedings of the $2^{\text {nd }}$ IEEE International Conference on Image Information Processing (ICIIP-2013).

[3] Permata E, 2013. "Klasifikasi Parasit Malaria Plasmodium Vivax Pada Citra Sel Darah Merah Menggunakan Metode Support Vector Machine One Against All", Universitas Sultan Ageng Tirtayasa.

[4] Khatkar \& Kumar, 2015. "Biomedical Image Enhancement Using Wavelets", International Conference on Intelligent Computing, Communication \& Convergence (ICCC-2015).

[5] Joey S. et al, 2013. "Aplikasi Laboratorium Kimia Virtual Viclab untuk Pelajar SMA Berbasis Android Menggunakan LIBGDX", Binus University Jakarta.

[6] Kendal, 2008. "Analisis dan Perancangan Sistem Jilid 1 Edisi Kelima", Jakarta. PT. Prehanlindo. 